\title{
Understanding Global HIV Stigma and Discrimination: Are Contextual Factors Sufficiently Studied? (GAPRESEARCH)
}

\author{
Bach Xuan Tran ${ }^{1,2, *(\mathbb{D}, \text { Hai Thanh Phan }}{ }^{3}$, Carl A. Latkin ${ }^{2}$, , Huong Lan Thi Nguyen ${ }^{3}$, \\ Chi Linh Hoang ${ }^{4}$, Cyrus S.H. Ho ${ }^{5}$ (D) and Roger C.M. Ho ${ }^{4,6,7}$ (D) \\ 1 Institute for Preventive Medicine and Public Health, Hanoi Medical University, Hanoi 100000, Vietnam \\ 2 Bloomberg School of Public Health, Johns Hopkins University, Baltimore, MD 21206, USA; \\ carl.latkin@jhu.edu \\ 3 Institute for Global Health Innovations, Duy Tan University, Da Nang 550000, Vietnam; \\ haipt.ighi@gmail.com (H.T.P.); huong.ighi@gmail.com (H.L.T.N.) \\ 4 Center of Excellence in Behavioral Medicine, Nguyen Tat Thanh University, Ho Chi Minh City, \\ Vietnam 700000, Vietnam; chi.coentt@gmail.com (C.L.H.); pcmrhcm@nus.edu.sg (R.C.M.H.) \\ 5 Department of Psychological Medicine, National University Hospital, Singapore 117599, Singapore; \\ cyrushosh@gmail.com \\ 6 Department of Psychological Medicine, Yong Loo Lin School of Medicine, National University of Singapore, \\ Singapore 117599, Singapore \\ 7 Institute for Health Innovation and Technology (iHealthtech) National University of Singapore, \\ Singapore 117599, Singapore \\ * Correspondence: bach.ipmph@gmail.com; Tel.: +84-982228662
}

Received: 30 April 2019; Accepted: 27 May 2019; Published: 29 May 2019

check for updates

\begin{abstract}
Stigma and discrimination are among the greatest challenges that people living with human immunodeficiency virus (HIV) face, and both are known to negatively affect quality of life as well as treatment outcomes. We analyzed the growing research and current understanding of HIV-related stigma and contextual factors in HIV/AIDS (human Immunodeficiency virus/ acquired immunodeficiency syndrome) bibliography. A total of 5984 publications published from 1991 to 2017 were retrieved from the Web of Science database. The number of papers and their impacts have been considerably grown in recent years. Research landscapes related to stigma and discrimination include clinical, physical and mental health outcomes, risk behaviors of most-at-risk populations, and HIV-related services. We found a lack of empirical studies not only on social, cultural and economic contexts, but also on specific interventions for particular settings and sub-populations. This study highlights certain gaps and provides a basis for future studies and interventions on this critical issue given the changing drivers of HIV epidemics.
\end{abstract}

Keywords: scientometrics; HIV; stigma; discrimination; contextual factors

\section{Introduction}

According by WHO, the human immunodeficiency virus (HIV) is the virus that can destroy or impair immune system function and lead to acquired immunodeficiency syndrome (AIDS) which is known as the most advanced stages of HIV infection [1]. By the end of 2017, there were 36.9 million people living with HIV worldwide, with 1.8 million new infection cases and 940,000 deaths [2]. Therefore, HIV/AIDS is considered as a global health burden [3]. The ongoing HIV epidemic requires continued and novel strategies in order to address the biomedical and psychosocial nature of the disease $[4,5]$. 
Since its identification nearly 40 years ago [6,7], one of the toughest challenges faced by people living with HIV (PLWH) is social stigma and discrimination [8]. According to the sociologist Erving Goffman, stigma can be defined as "an attribute that links a person to an undesirable stereotype, leading other people to reduce the bearer from a whole and usual person to a tainted, discounted one" [9]. Stigma and discrimination are not only fuel the spread of epidemics, but also impact patients in their responses and living with HIV/AIDS by social isolation, stress and emotional coping, and denial of social and economic resources [5,10]. Despite much intensive understandings of HIV and advancements in HIV treatment, studies have recorded HIV stigma and discrimination within interpersonal, community, and healthcare environments. Discriminatory attitudes, HIV testing without consent, refusal of care and treatment, and confidentiality violation have been observed in a large number of healthcare workers [11-13]. A study by Wagner also reported high levels of discrimination and even overlapping stigmas held by health care providers in such a developed country as Canada [14].

Stigma and discrimination have affected PLWH's life in many ways, and most of them are detrimental. HIV-related stigma is often associated with psychological distress, such as shame [15], depression [16], anxiety [17,18], suicidal ideation [19] and quality of life [20-22]. Furthermore, stigma towards PLWH in healthcare settings is considered one of the major barriers to optimal treatment. Numerous studies suggest that experiences of HIV-related stigma resulted in lower access to HIV treatment, low utilization of HIV care services, poorer antiretroviral therapy (ART) adherence, and thus poorer treatment outcomes $[12,13,23]$.

Although a growing body of literature has expressed the interest in this topic, most research has focused on general issues related to HIV stigma. Marshall et al. measured the HIV-related discrimination among healthcare providers [13]. A systematic review conducted by Rueda et al. examined the associations between HIV-related stigma and health outcomes in PLWH [24]. These and other reviews provided a summary of research in this field, however, did not fully describe the trends in research and intervention designs as well as the emergence of research approaches over time. Quantifying the growth in studies and usage, which is defined as the total downloads, as well as characterizing research domains are beneficial for informing priority settings and programming, especially in a particular context. This study aims to measure the international growth in specific research interests by evaluating the tendency of research topics of published articles over time and establishing a network of research collaborations based on published literature. We also delineated the development of research landscapes for factors associated with HIV stigma and discrimination among PLWH.

\section{Materials and Methods}

\subsection{Search Strategy}

A cross-sectional study for HIV/AIDS bibliography analysis was designed based on the Web of Science database. The search query of keywords consisted of HIV; human-immunodeficiency-virus, AIDS, and acquired-immune-deficiency-syndrome. We selected two types of research paper, namely research articles and research reviews, and excluded other document types (e.g., books, book chapters or data papers). The language and publication date were also restricted. The publications in English until 2017 were chosen because this study was performed in the middle of 2018. Thus, the data produced in the first half of the year may not fully reflect the trend of the entire year. The second step was to select papers mentioning stigma and discrimination in the Abstracts or Titles.

\subsection{Data Extraction}

Data, including authors' names, the papers' titles, the journals' names, keywords, institutional affiliations, the frequency of citation, subject categories, and abstracts, were downloaded from the Web of Science database. In addition, the citation reports automatically created by the Web of Science were also downloaded. All data were converted to xlsm form (Microsoft Excel) for data checking of errors. 
In order to bring together the different names of an author, a process of standardization was carried out by two researchers (Figure 1).

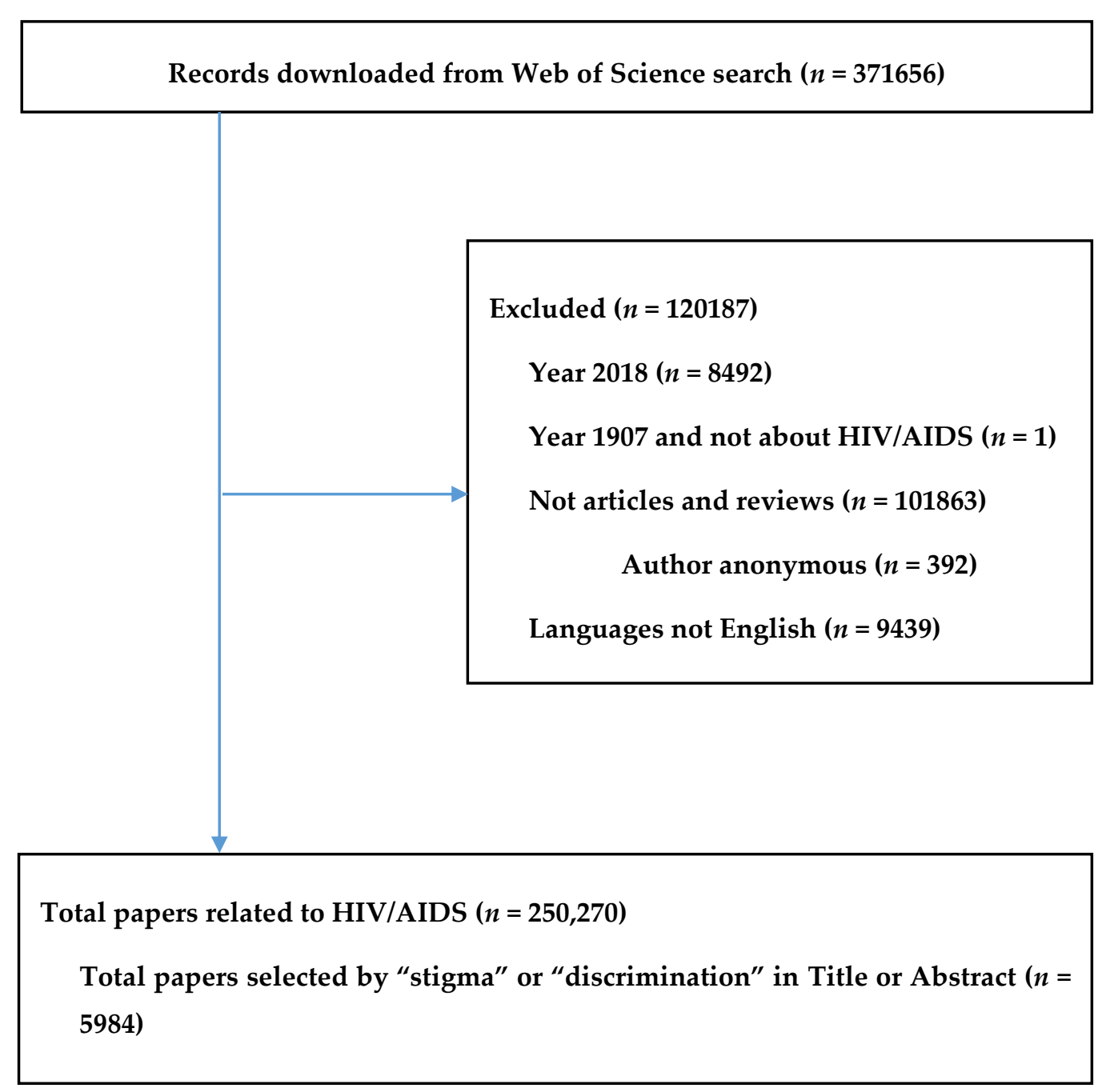

Figure 1. Selection of papers.

\subsection{Data Analysis}

We analyzed data based on general characteristics (publication years, main categories, number of authors), keywords (co-occurrence keywords and most common keywords), citations, usages, and abstracts. After downloading and extracted data, we applied Macro, a programming code run on Excel, to calculate countries' citation, intra- and inter-country collaboration. The connection among countries sharing the co-authorships was illustrated by a network graph. The author keyword co-occurrence network and countries network were also created by VOSviewer (version 1.6.8, Center for Science and Technology, Leiden University, Leiden, the Netherlands). We applied exploratory factor analysis to identify research domains emerging from all contents of the abstracts; loadings of 0.4. Jaccard's similarity index was utilized to identify research topics or terms most frequently co-occurring with each other. It was defined as the size of the intersection divided by the size of the union of two sets of co-occurring terms. We created illustrations of the proximity values computed on all analyzed keywords using multidimensional scaling. In the map, a point represented a topic category, and the distances between pairs of items revealed to what extent those items appeared together. Colors represented the membership of specific items to different partitions created using hierarchical clustering. 
Stata software was used for statistical analyses. Analysis of each type of text data are presented as follows (Table 1):

Table 1. Type of data and analytical methods.

\begin{tabular}{|c|c|c|c|}
\hline Type of Data & Unit of Analysis & Analytical Methods & Presentations of Results \\
\hline Key words, Countries & Words & $\begin{array}{l}\text { Frequency of } \\
\text { co-occurrence }\end{array}$ & $\begin{array}{l}\text { (1) Map of keywords } \\
\text { clusters }\end{array}$ \\
\hline Abstracts & Words & $\begin{array}{l}\text { Exploratory factors } \\
\text { analyses }\end{array}$ & $\begin{array}{l}\text { (2) Top } 50 \text { constructed } \\
\text { research domains } \\
\text { (3) Clustering map of the } \\
\text { landscapes constructed } \\
\text { by these domains. }\end{array}$ \\
\hline Abstracts & Papers & $\begin{array}{l}\text { Latent Dirichlet } \\
\text { Allocation }\end{array}$ & $\begin{array}{l}\text { (4) } 10 \text { classifications of } \\
\text { research topics }\end{array}$ \\
\hline $\begin{array}{l}\text { WoS classification of } \\
\text { research areas }\end{array}$ & WoS research areas & $\begin{array}{l}\text { Frequency of } \\
\text { co-occurrence }\end{array}$ & $\begin{array}{l}\text { (5) Dendrogram of } \\
\text { research disciplines (WoS } \\
\text { classification) }\end{array}$ \\
\hline
\end{tabular}

\section{Results}

\subsection{Number of Published Items and Publication Trend}

The paper selection process is displayed in Figure 1. Among 250,270 articles in 153 HIV related research areas, 5984 papers including the terms "stigma" or "discrimination" in the title or abstract were selected and analyzed.

The number of papers counted by study settings of 125 countries is presented in Table 2 . The American population appears to be the most well-studied one with 406 cases, accounting for $14.26 \%$ of the total sample.

The increasing number of papers on discrimination towards people living with HIV/AIDS can be observed from Table 3. Throughout the last decade, the number of papers has been considerably grown and reached 633 articles in 2017, tripling that of 2007 and making up over 15\% of total HIV/AIDS studies. Notably, the total usage of the last five years of 2003 is about 3-4 times higher compared to the previous years. Total citations and usage rates have also risen remarkably, especially from 2003. Particularly, in terms of mean use rate of the last five years, the figures for the years 2003 and 2013 were the largest throughout the research period. 
Table 2. Number of paper by study settings.

\begin{tabular}{|c|c|c|c|c|c|c|c|c|c|c|c|}
\hline$\#$ & Country & Freq. & Percent & $\#$ & Country & Freq. & Percent & $\#$ & Country & Freq. & Percent \\
\hline 1 & United States & 406 & 14.26 & 42 & Rwanda & 10 & 0.35 & 84 & Sri Lanka & 3 & 0.11 \\
\hline 2 & South Africa & 380 & 13.34 & 43 & Spain & 10 & 0.35 & 85 & Tajikistan & 3 & 0.11 \\
\hline 3 & China & 230 & 8.08 & 44 & New Zealand & 9 & 0.32 & 86 & Togo & 3 & 0.11 \\
\hline 4 & India & 177 & 6.21 & 45 & Senegal & 9 & 0.32 & 87 & Trinidad and Tobago & 3 & 0.11 \\
\hline 5 & Uganda & 127 & 4.46 & 46 & Taiwan & 9 & 0.32 & 88 & Turkey & 3 & 0.11 \\
\hline 6 & Kenya & 116 & 4.07 & 47 & Burkina Faso & 8 & 0.28 & 89 & Albania & 2 & 0.07 \\
\hline 7 & Canada & 104 & 3.65 & 48 & Georgia & 8 & 0.28 & 90 & Bolivia & 2 & 0.07 \\
\hline 8 & Tanzania & 82 & 2.88 & 49 & Ukraine & 8 & 0.28 & 91 & Cuba & 2 & 0.07 \\
\hline 9 & Australia & 73 & 2.56 & 50 & Argentina & 7 & 0.25 & 92 & Czech & 2 & 0.07 \\
\hline 10 & Viet Nam & 67 & 2.35 & 51 & Chile & 7 & 0.25 & 93 & Gabon & 2 & 0.07 \\
\hline 11 & Ethiopia & 59 & 2.07 & 52 & Guatemala & 7 & 0.25 & 94 & Gambia & 2 & 0.07 \\
\hline 12 & Thailand & 50 & 1.76 & 53 & Italy & 7 & 0.25 & 95 & Hungary & 2 & 0.07 \\
\hline 13 & Brazil & 44 & 1.54 & 54 & Lao & 7 & 0.25 & 96 & Kazakhstan & 2 & 0.07 \\
\hline 14 & Ghana & 44 & 1.54 & 55 & Pakistan & 7 & 0.25 & 97 & Libya & 2 & 0.07 \\
\hline 15 & Malawi & 44 & 1.54 & 56 & Bangladesh & 6 & 0.21 & 98 & Madagascar & 2 & 0.07 \\
\hline 16 & Botswana & 43 & 1.51 & 57 & Barbados & 6 & 0.21 & 99 & Mali & 2 & 0.07 \\
\hline 17 & United Kingdom & 43 & 1.51 & 58 & Colombia & 6 & 0.21 & 100 & Philippines & 2 & 0.07 \\
\hline 18 & Zimbabwe & 43 & 1.51 & 59 & Greece & 6 & 0.21 & 101 & Suriname & 2 & 0.07 \\
\hline 19 & Zambia & 40 & 1.40 & 60 & Sudan & 6 & 0.21 & 102 & Wallis and Futuna & 2 & 0.07 \\
\hline 20 & Ireland & 31 & 1.09 & 61 & Belgium & 5 & 0.18 & 103 & Afghanistan & 1 & 0.04 \\
\hline 21 & Japan & 23 & 0.81 & 62 & Estonia & 5 & 0.18 & 104 & Angola & 1 & 0.04 \\
\hline 22 & Mexico & 23 & 0.81 & 63 & Germany & 5 & 0.18 & 105 & Benin & 1 & 0.04 \\
\hline 23 & Indonesia & 22 & 0.77 & 64 & Singapore & 5 & 0.18 & 106 & Bulgaria & 1 & 0.04 \\
\hline 24 & Peru & 22 & 0.77 & 65 & United Arab Emirates & 5 & 0.18 & 107 & Burundi & 1 & 0.04 \\
\hline 25 & Hong Kong & 21 & 0.74 & 66 & Yemen & 5 & 0.18 & 108 & Central African Republic & 1 & 0.04 \\
\hline 26 & Namibia & 21 & 0.74 & 67 & El Salvador & 4 & 0.14 & 109 & Cyprus & 1 & 0.04 \\
\hline 27 & Puerto Rico & 21 & 0.74 & 68 & Myanmar & 4 & 0.14 & 110 & Denmark & 1 & 0.04 \\
\hline 28 & Malaysia & 20 & 0.70 & 69 & Portugal & 4 & 0.14 & 111 & Fiji & 1 & 0.04 \\
\hline 29 & Iran & 19 & 0.67 & 70 & Russian Federation & 4 & 0.14 & 112 & French Guiana & 1 & 0.04 \\
\hline 30 & Nepal & 18 & 0.63 & 71 & Saudi Arabia & 4 & 0.14 & 113 & Grenada & 1 & 0.04 \\
\hline
\end{tabular}


Table 2. Cont.

\begin{tabular}{|c|c|c|c|c|c|c|c|c|c|c|c|}
\hline$\#$ & Country & Freq. & Percent & $\#$ & Country & Freq. & Percent & $\#$ & Country & Freq. & Percent \\
\hline 31 & Swaziland & 16 & 0.56 & 72 & Switzerland & 4 & 0.14 & 114 & Guinea & 1 & 0.04 \\
\hline 32 & France & 15 & 0.53 & 73 & Croatia & 3 & 0.11 & 115 & Jersey & 1 & 0.04 \\
\hline 33 & Mozambique & 15 & 0.53 & 74 & Egypt & 3 & 0.11 & 116 & Macedonia & 1 & 0.04 \\
\hline 34 & Jamaica & 14 & 0.49 & 75 & Guyana & 3 & 0.11 & 117 & Micronesia & 1 & 0.04 \\
\hline 35 & Cambodia & 13 & 0.46 & 76 & Honduras & 3 & 0.11 & 118 & Mongolia & 1 & 0.04 \\
\hline 36 & Netherlands & 13 & 0.46 & 77 & Israel & 3 & 0.11 & 119 & Morocco & 1 & 0.04 \\
\hline 37 & Cameroon & 11 & 0.39 & 78 & Jordan & 3 & 0.11 & 120 & Romania & 1 & 0.04 \\
\hline 38 & Haiti & 11 & 0.39 & 79 & Kyrgyzstan & 3 & 0.11 & 121 & Solomon Islands & 1 & 0.04 \\
\hline 39 & Sweden & 11 & 0.39 & 80 & Nicaragua & 3 & 0.11 & 122 & Somalia & 1 & 0.04 \\
\hline 40 & Lebanon & 10 & 0.35 & 81 & Poland & 3 & 0.11 & 123 & Timor-Leste & 1 & 0.04 \\
\hline \multirow[t]{2}{*}{41} & Lesotho & 10 & 0.35 & 82 & Serbia & 3 & 0.11 & 124 & Tunisia & 1 & 0.04 \\
\hline & & & & 83 & Sierra Leone & 3 & 0.11 & 125 & Uruguay & 1 & 0.04 \\
\hline
\end{tabular}


Table 3. General characteristics of publications.

\begin{tabular}{cccccccc}
\hline $\begin{array}{c}\text { Year } \\
\text { Published }\end{array}$ & $\begin{array}{c}\text { Total \# } \\
\text { Papers }\end{array}$ & $\begin{array}{c}\text { Total } \\
\text { Citations }\end{array}$ & $\begin{array}{c}\text { Mean Cite } \\
\text { Rate Per Year }\end{array}$ & $\begin{array}{c}\text { Total Usage } \\
\text { Last 6 Month }\end{array}$ & $\begin{array}{c}\text { Total Usage } \\
\text { Last 5 Years }\end{array}$ & $\begin{array}{c}\text { Mean Use } \\
\text { Rate Last } \\
\text { 6 Month }\end{array}$ & $\begin{array}{c}\text { Mean Use } \\
\text { Rate Last } \\
\text { 5 Year }\end{array}$ \\
\hline 2017 & 633 & 806 & 1.27 & 1150 & 3455 & 1.82 & 1.09 \\
2016 & 661 & 2418 & 1.83 & 712 & 5409 & 1.08 & 1.64 \\
2015 & 632 & 4208 & 2.22 & 481 & 5930 & 0.76 & 1.88 \\
2014 & 493 & 5691 & 2.89 & 363 & 5756 & 0.74 & 2.34 \\
2013 & 520 & 8340 & 3.21 & 337 & 7136 & 0.65 & 2.74 \\
2012 & 418 & 6992 & 2.79 & 172 & 4369 & 0.41 & 2.09 \\
2011 & 356 & 6544 & 2.63 & 159 & 3068 & 0.45 & 1.72 \\
2010 & 340 & 6818 & 2.51 & 131 & 2388 & 0.39 & 1.40 \\
2009 & 286 & 7486 & 2.91 & 125 & 2133 & 0.44 & 1.49 \\
2008 & 284 & 8846 & 3.11 & 127 & 1897 & 0.45 & 1.34 \\
2007 & 243 & 7669 & 2.87 & 107 & 1521 & 0.44 & 1.25 \\
2006 & 184 & 6523 & 2.95 & 58 & 1052 & 0.32 & 1.14 \\
2005 & 146 & 6606 & 3.48 & 67 & 920 & 0.46 & 1.26 \\
2004 & 98 & 4542 & 3.31 & 43 & 634 & 0.44 & 1.29 \\
2003 & 81 & 7844 & 6.46 & 86 & 1099 & 1.06 & 2.71 \\
2002 & 68 & 2874 & 2.64 & 25 & 284 & 0.37 & 0.84 \\
2001 & 59 & 3175 & 3.17 & 18 & 334 & 0.31 & 1.13 \\
2000 & 69 & 3491 & 2.81 & 28 & 395 & 0.41 & 1.14 \\
1999 & 53 & 2396 & 2.38 & 12 & 226 & 0.23 & 0.85 \\
1998 & 40 & 1021 & 1.28 & 11 & 123 & 0.28 & 0.62 \\
1997 & 54 & 3866 & 3.41 & 14 & 213 & 0.26 & 0.79 \\
1996 & 53 & 1704 & 1.46 & 9 & 159 & 0.17 & 0.60 \\
1995 & 46 & 2460 & 2.33 & 12 & 189 & 0.26 & 0.82 \\
1994 & 31 & 1776 & 2.39 & 8 & 132 & 0.26 & 0.85 \\
1993 & 26 & 960 & 1.48 & 5 & 69 & 0.19 & 0.53 \\
1992 & 24 & 1539 & 2.47 & 4 & 111 & 0.17 & 0.93 \\
1991 & 12 & 565 & 1.74 & 2 & 24 & 0.17 & 0.40 \\
\hline
\end{tabular}

\subsection{Authors and Collaborations}

The global network among 97 countries having co-authorship of selected papers is illustrated in Figure 2. The figure was constructed by counting the co-occurrence of different countries in the authors' affiliations, and clustering them into groups of countries with similar level of co-authorship with other countries. The size of nodes is proportional to the contribution to the number of papers and the thickness of lines represents the percentage of the number of collaboration. These countries have been classified into 9 clusters of at least five countries depending on their level of international collaborations. Each color indicates a level of international co-authorship. Apart from leading nations in global HIV initiatives, such as the United States or the United Kingdom, regional neighbors or countries sharing the same languages tend to have similar levels of international co-authorship.

\subsection{Keywords and Research Domains}

Figure 3 reveals the principal components of the keywords structure with the most frequent groups of terms. There were five major clusters emerging from 406 most frequent keywords co-occurrence of 20 times and higher. Cluster 1 (red) refers to prevention of HIV transmissions through sex or blood in particular subjects, including transgender, bisexual men, female sex workers and injecting drug users, in America, India, and Thailand. Cluster 2 (green) focuses on HIV medication adherence and associated matters in several African countries. Cluster 3 (yellow) reveals social issues relating to the mental health of young adults and homosexuals in the United States. Cluster 4 (blue) describes experiences of families having members with HIV-related chronic illnesses, while cluster 5 (purple) mentions two types of HIV/AIDS stigma, which are self-stigma and perceived stigma.

The top 50 research domains and keywords emerged from the exploratory factor analysis of all abstracts' contents are listed in Table 4. Men who have sex with men, care providers, and female sex workers were the top three domains attracting greatest interest and each accounted for nearly half of 
total cases. Stigma and discrimination relating research domains focused on risk behaviors, clinical and quality of life outcomes, and HIV-related services uptake. Contextual factors were only found in domain \# 32, which was cultural beliefs.

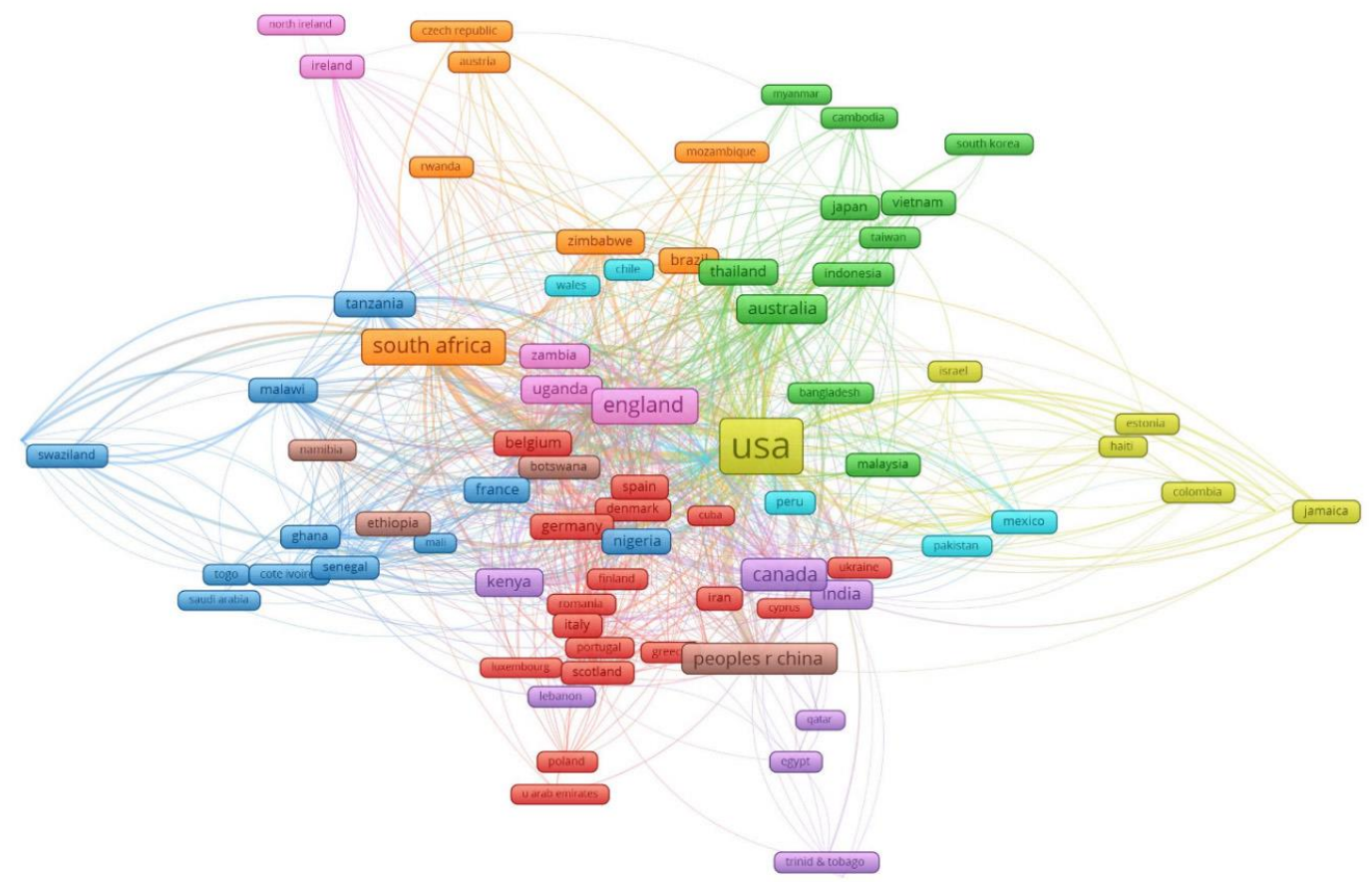

Figure 2. The global networking of 97 countries having co-authorships in stigma research in HIV/AIDS.

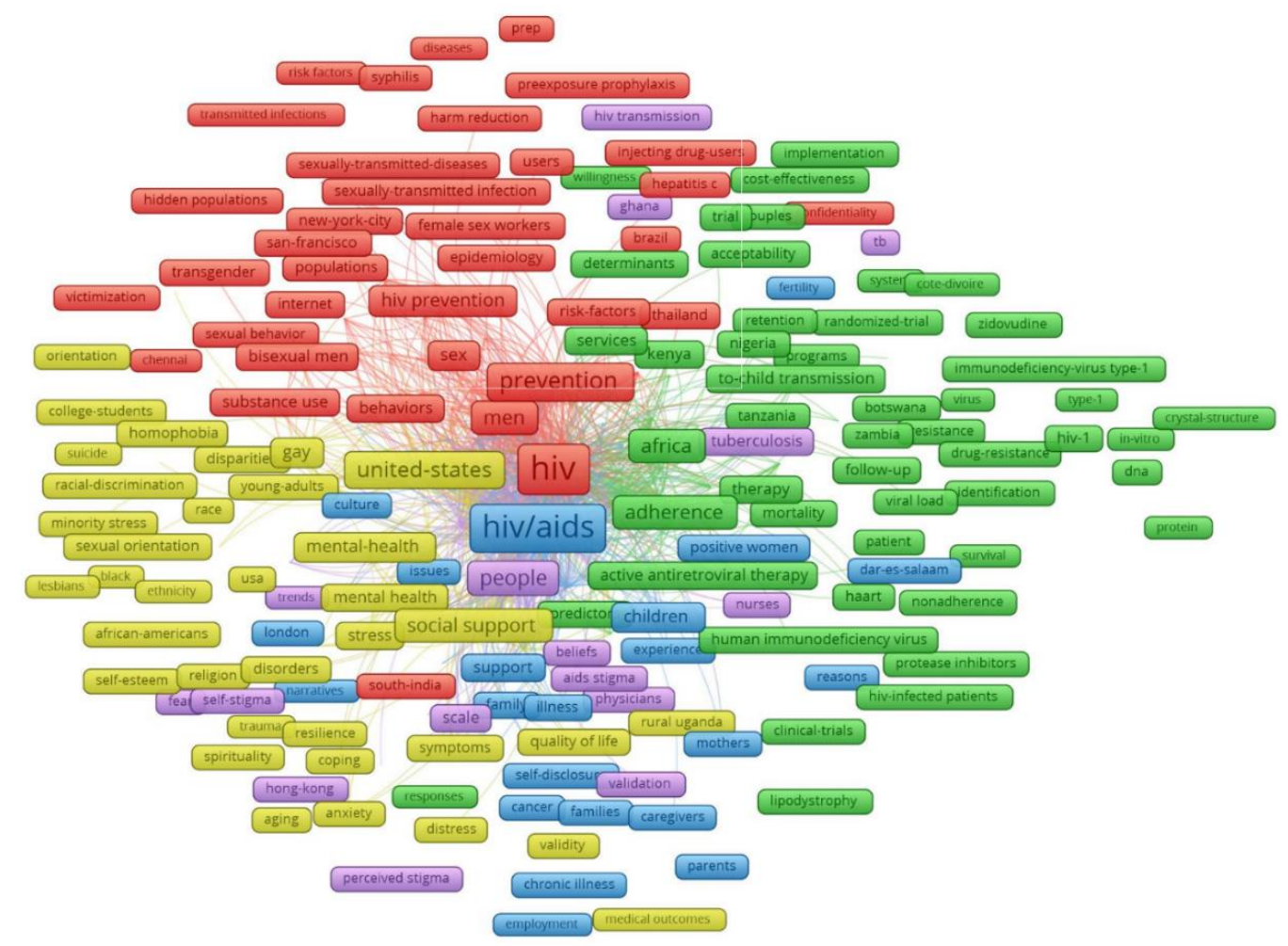

Figure 3. Co-occurrence of most frequent author's keywords. Note: the colors of the nodes refer to principal components of the data structure; the nodes size was scaled to the keywords' occurrences; the thickness of the lines was drawn based on the strength of the association between two keywords. 
Table 4. Top 50 research domains emerged from exploratory factor analysis of all abstracts' contents.

\begin{tabular}{|c|c|c|c|c|c|}
\hline No & Name & Keywords & Eigenvalue & Freq. & $\%$ Cases \\
\hline 1 & Men (Msm; Sex Sexual) & msm; men; sex; sexual; risk & 4.71 & 6175 & $50.94 \%$ \\
\hline 2 & Care Providers & providers; provider; service; care; services; healthcare & 1.61 & 5107 & $48.18 \%$ \\
\hline 3 & Fsws; Female Sex & fsws; female; workers; clients; work; sex & 1.75 & 3542 & $39.24 \%$ \\
\hline 4 & Sexual Partners & partners; partner; sexual; disclosure; communication & 1.28 & 3347 & $38.17 \%$ \\
\hline 5 & Antiretroviral; Therapy & antiretroviral; therapy; adherence; medication; treatment; taking & 2.63 & 4236 & $37.58 \%$ \\
\hline 6 & Dna; Rt & dna; rt; viral; discrimination & 1.92 & 2449 & $36.15 \%$ \\
\hline 7 & Testing & $\begin{array}{c}\text { testing; vct; test; counselling; uptake; tested; counseling; } \\
\text { confidentiality }\end{array}$ & 2.06 & 3227 & $31.50 \%$ \\
\hline 8 & Reduction Intervention & intervention; trial; reduction; follow; control; reducing & 2.27 & 2586 & $31.40 \%$ \\
\hline 9 & Gender; Transgender & gender; transgender; women; identity & 1.29 & 2412 & $31.23 \%$ \\
\hline 10 & Depression and Anxiety; Psychological & $\begin{array}{c}\text { anxiety; depression; psychological; distress; symptoms; mental; } \\
\text { stress; psychosocial; physical }\end{array}$ & 4.19 & 3187 & $28.76 \%$ \\
\hline 11 & Children; Parents & children; parents; families; caregivers; family; affected & 2.46 & 2544 & $27.82 \%$ \\
\hline 12 & Gay Men & gay; bisexual; men; identity & 1.42 & 2156 & $25.20 \%$ \\
\hline 13 & Chronic Illness & illness; chronic; disease; conditions & 2.48 & 1834 & $24.60 \%$ \\
\hline 14 & Scale Scores; Factor & scale; factor; scores; developed; measures & 1.35 & 1771 & $23.16 \%$ \\
\hline 15 & General Population & general; population & 1.48 & 1522 & $21.77 \%$ \\
\hline 16 & Family Members & members; family; network & 1.28 & 1466 & $19.45 \%$ \\
\hline 17 & Coping Strategies & coping; internalized; strategies & 1.18 & 1262 & $18.63 \%$ \\
\hline 18 & Policy and Practice & practice; implications; policy & 1.18 & 1300 & $18.55 \%$ \\
\hline 19 & Substance Abuse & abuse; substance; alcohol; mental; violence & 1.67 & 1517 & $18.37 \%$ \\
\hline 20 & South Africa & africa; saharan; south & 1.69 & 1745 & $17.06 \%$ \\
\hline 21 & Transmission (PMTCT) & pmtct; mothers; transmission & 1.63 & 1124 & $16.34 \%$ \\
\hline 22 & QoL; Life Quality & qol; quality; life & 1.5 & 1287 & $16.06 \%$ \\
\hline 23 & Youth; Adults and Adolescents & youth; adolescents; young; adults & 1.78 & 1181 & $15.74 \%$ \\
\hline 24 & Income Countries & income; countries; global & 3.09 & 1140 & $15.54 \%$ \\
\hline 25 & Human Immunodeficiency & immunodeficiency; human & 1.39 & 1460 & $14.97 \%$ \\
\hline 26 & Behavior & behavior; behaviors & 1.15 & 951 & $13.52 \%$ \\
\hline 27 & Staff Training & staff; management; training & 1.19 & 923 & $13.49 \%$ \\
\hline 28 & Sexually Transmitted & transmitted; sexually; infections; sti & 2.11 & 1384 & $12.77 \%$ \\
\hline 29 & Drug Users & users; drug & 1.45 & 968 & $12.63 \%$ \\
\hline 30 & Black; States & black; states; american & 1.25 & 805 & $11.75 \%$ \\
\hline
\end{tabular}


Table 4. Cont.

\begin{tabular}{|c|c|c|c|c|c|}
\hline No & Name & Keywords & Eigenvalue & Freq. & $\%$ Cases \\
\hline 31 & Majority & majority; respondents & 1.27 & 753 & $11.66 \%$ \\
\hline 32 & Cultural Beliefs & beliefs; cultural & 1.24 & 750 & $11.33 \%$ \\
\hline 33 & Association of Nurses & nurses; plwh; association & 1.44 & 762 & $11.25 \%$ \\
\hline 34 & Demographic Characteristics & characteristics; demographic & 1.38 & 743 & $10.51 \%$ \\
\hline 35 & Urban and Rural & rural; urban & 1.31 & 751 & $10.46 \%$ \\
\hline 36 & Counselling & counselling programme; programmes; & 1.81 & 737 & $10.16 \%$ \\
\hline 37 & Structural & structural & 1.14 & 514 & $8.59 \%$ \\
\hline 38 & Vaccine Trial & vaccine; trial; participation & 1.38 & 567 & $8.19 \%$ \\
\hline 39 & Order & order & 1.25 & 421 & $7.04 \%$ \\
\hline 40 & Common & common & 1.16 & 420 & $7.02 \%$ \\
\hline 41 & Prep & prep; exposure & 1.54 & 365 & $5.06 \%$ \\
\hline 42 & Resources & resources & 1.22 & 296 & $4.95 \%$ \\
\hline 43 & Behaviour & behaviour & 1.13 & 289 & $4.83 \%$ \\
\hline 44 & Tuberculosis (Tb & tb; tuberculosis & 1.86 & 333 & $3.59 \%$ \\
\hline 45 & Home & home & 1.21 & 198 & $3.31 \%$ \\
\hline 46 & India & india & 1.23 & 195 & $3.26 \%$ \\
\hline 47 & Screening & screening & 1.56 & 195 & $3.26 \%$ \\
\hline 48 & PLHIV & plhiv & 1.18 & 154 & $2.57 \%$ \\
\hline 49 & Hepatitis & hepatitis; hcv & 1.98 & 213 & $2.52 \%$ \\
\hline 50 & Sexual & couple; disclosure; & 1.25 & 145 & $2.39 \%$ \\
\hline
\end{tabular}


Exploratory factor analysis of abstracts' contents also emerged co-occurrence of most frequent topics (Figure 4). A wide range of topics, such as outcomes of interventions, treatment and prevention, the role of social support and services, sexual transmission, and impact of discrimination and stigma, are specified in green nodes. Red nodes mention physical, psychological and social problems of people living with HIV/AIDS in general, whereas cluster in cobalt blue focuses on cross-sectional studies of the LGBT population. Brown cluster reveals the literature review of national policies and evidence of this epidemic. The remaining scatters on the right of the figure includes various issues. HIV testing and counseling, stigmatization of people living with HIV, vaccination and HIV-associated chronic diseases, for example, are the major concerns.

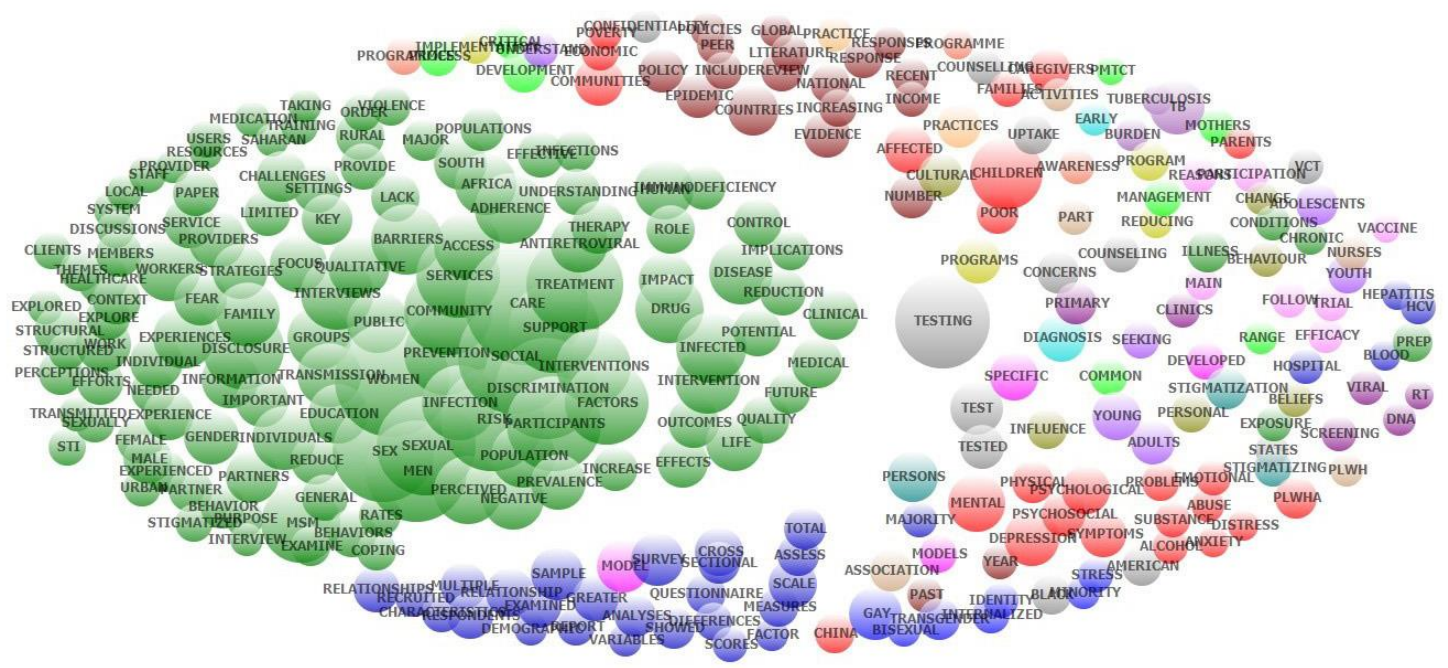

Figure 4. Co-occurrence of most frequent topics emerged from exploratory factor analysis of abstracts contents.

Table 5 presents the most cited papers discussing interventions and trials related to stigma and HIV/AIDS. It depicts that the interests and preferences of the research community to approach stigma and discrimination include two main areas: (1) contextual factors including social, cultural, psycho-behaviors, gender, family and community and (2) the implementation of HIV vaccine trial. 
Table 5. Most cited papers mentioning interventions.

\begin{tabular}{|c|c|c|c|c|c|}
\hline \# & Title & Journal & Citations & Years & Cite Rate \\
\hline 1 & Interventions to reduce HIV/AIDs stigma: What have we learned? & Aids Education And Prevention & 413 & 2003 & 27.5 \\
\hline 2 & $\begin{array}{c}\text { AIDS-related Kaposi's sarcoma: Prospective validation of the AIDS } \\
\text { Clinical Trials Group staging classification }\end{array}$ & Journal Of Clinical Oncology & 156 & 1997 & 7.4 \\
\hline 3 & $\begin{array}{l}\text { A systematic review of interventions to reduce HIV-related stigma } \\
\text { and discrimination from } 2002 \text { to 2013: how far have we come? }\end{array}$ & $\begin{array}{l}\text { Journal Of The International Aids } \\
\text { Society }\end{array}$ & 136 & 2013 & 27.2 \\
\hline 4 & $\begin{array}{l}\text { HIV Interventions to Reduce HIV/AIDS Stigma: A Systematic } \\
\text { Review }\end{array}$ & Aids And Behavior & 135 & 2011 & 19.3 \\
\hline 5 & $\begin{array}{c}\text { Health work, female sex workers and HIV/AIDS: Global and local } \\
\text { dimensions of stigma and deviance as barriers to effective } \\
\text { interventions }\end{array}$ & Social Science \& Medicine & 95 & 2008 & 9.5 \\
\hline 6 & $\begin{array}{l}\text { Willingness to volunteer in future preventive HIV vaccine trials: } \\
\text { Issues and perspectives from three US communities }\end{array}$ & $\begin{array}{l}\text { Journal Of Acquired Immune } \\
\text { Deficiency Syndromes }\end{array}$ & 84 & 2001 & 4.9 \\
\hline 7 & $\begin{array}{l}\text { A Qualitative Study of the Barriers and Facilitators to } \\
\text { Retention-in-Care Among HIV-Positive Women in the Rural } \\
\text { Southeastern United States: Implications for Targeted Interventions }\end{array}$ & Aids Patient Care And STDs & 77 & 2010 & 9.6 \\
\hline 8 & $\begin{array}{c}\text { Getting me back on track": The role of outreach interventions in } \\
\text { engaging and retaining people living with HIV/AIDS in medical } \\
\text { care }\end{array}$ & Aids Patient Care And STDs & 72 & 2007 & 6.5 \\
\hline 9 & $\begin{array}{c}\text { Linking sexual and reproductive health and HIV interventions: a } \\
\text { systematic review }\end{array}$ & $\begin{array}{l}\text { Journal Of The International Aids } \\
\text { Society }\end{array}$ & 70 & 2010 & 8.8 \\
\hline 10 & $\begin{array}{c}\text { Global burden, distribution, and interventions for infectious } \\
\text { diseases of poverty }\end{array}$ & Infectious Diseases Of Poverty & 67 & 2014 & 16.8 \\
\hline 11 & $\begin{array}{l}\text { Who Gets Tested for HIV in a South African Urban Township? } \\
\text { Implications for Test and Treat and Gender-Based Prevention } \\
\text { Interventions }\end{array}$ & $\begin{array}{l}\text { Journal Of Acquired Immune } \\
\text { Deficiency Syndromes }\end{array}$ & 59 & 2011 & 8.4 \\
\hline 12 & $\begin{array}{l}\text { Transgender stigma and health: A critical review of stigma } \\
\text { determinants, mechanisms, and interventions }\end{array}$ & Social Science \& Medicine & 54 & 2015 & 18.0 \\
\hline
\end{tabular}


Table 5. Cont

\begin{tabular}{|c|c|c|c|c|c|}
\hline$\#$ & Title & Journal & Citations & Years & Cite Rate \\
\hline 13 & $\begin{array}{l}\text { Preventing discrimination against volunteers in prophylactic HIV } \\
\text { vaccine trials: Lessons from a phase II trial }\end{array}$ & $\begin{array}{l}\text { Journal Of Acquired Immune } \\
\text { Deficiency Syndromes And } \\
\text { Human Retrovirology }\end{array}$ & 42 & 1998 & 2.1 \\
\hline 14 & Trial-related discrimination in HIV vaccine clinical trials & $\begin{array}{l}\text { Aids Research And Human } \\
\text { Retroviruses }\end{array}$ & 40 & 2001 & 2.4 \\
\hline 15 & $\begin{array}{l}\text { Informing Faith-Based HIV/AIDS Interventions: HIV-Related } \\
\text { Knowledge and Stigmatizing Attitudes at Project FAITH Churches } \\
\text { in South Carolina }\end{array}$ & Public Health Reports & 33 & 2010 & 4.1 \\
\hline 16 & $\begin{array}{l}\text { Eliminating the latent HIV reservoir by reactivation strategies } \\
\text { Advancing to clinical trials }\end{array}$ & $\begin{array}{l}\text { Human Vaccines \& } \\
\text { Immunotherapeutics }\end{array}$ & 31 & 2013 & 6.2 \\
\hline 17 & $\begin{array}{c}\text { It's an Uphill Battle Everyday": Intersectionality, Low-Income } \\
\text { Black Heterosexual Men, and Implications for HIV Prevention } \\
\text { Research and Interventions }\end{array}$ & $\begin{array}{c}\text { Psychology Of Men \& } \\
\text { Masculinity }\end{array}$ & 31 & 2013 & 6.2 \\
\hline 18 & $\begin{array}{l}\text { A model for community representation and participation in HIV } \\
\text { prevention trials among women who engage in transactional sex in } \\
\text { Africa }\end{array}$ & $\begin{array}{l}\text { Aids Care-Psychological And } \\
\text { Socio-Medical Aspects Of } \\
\text { Aids/HIV }\end{array}$ & 27 & 2008 & 2.7 \\
\hline 19 & $\begin{array}{l}\text { Uptake of prevention of mother to child transmission interventions } \\
\text { in Kenya: health systems are more influential than stigma }\end{array}$ & $\begin{array}{l}\text { Journal Of The International Aids } \\
\text { Society }\end{array}$ & 26 & 2011 & 3.7 \\
\hline 20 & Why blacks do not take part in HIV vaccine trials & $\begin{array}{l}\text { Journal Of The National Medical } \\
\text { Association }\end{array}$ & 26 & 2007 & 2.4 \\
\hline 21 & $\begin{array}{l}\text { HIV prevention interventions to reduce sexual risk for African } \\
\text { Americans: The influence of community-level stigma and } \\
\text { psychological processes }\end{array}$ & Social Science \& Medicine & 26 & 2014 & 6.5 \\
\hline 22 & $\begin{array}{l}\text { Attitudes and beliefs related to HIV/AIDS in urban religious } \\
\text { congregations: Barriers and opportunities for HIV-related } \\
\text { interventions }\end{array}$ & Social Science \& Medicine & 25 & 2012 & 4.2 \\
\hline 23 & $\begin{array}{c}\text { What can HIV vaccine trials teach us about future HIV vaccine } \\
\text { dissemination? }\end{array}$ & Vaccine & 25 & 2008 & 2.5 \\
\hline 24 & Barriers to participation in HIV drug trials: a systematic review & Lancet Infectious Diseases & 22 & 2006 & 1.8 \\
\hline
\end{tabular}


Table 5. Cont

\begin{tabular}{|c|c|c|c|c|c|}
\hline$\#$ & Title & Journal & Citations & Years & Cite Rate \\
\hline 25 & $\begin{array}{l}\text { Interventions to Improve Psychological Functioning and Health } \\
\text { Outcomes of HIV-Infected Individuals with a History of Trauma or } \\
\text { PTSD }\end{array}$ & Current HIV/Aids Reports & 22 & 2012 & 3.7 \\
\hline 26 & $\begin{array}{l}\text { Interventions to reduce the sexual risk behaviour of injecting drug } \\
\text { users }\end{array}$ & $\begin{array}{c}\text { International Journal Of Drug } \\
\text { Policy }\end{array}$ & 21 & 2005 & 1.6 \\
\hline 27 & $\begin{array}{l}\text { Articulating A Rights-Based Approach to HIV Treatment and } \\
\text { Prevention Interventions }\end{array}$ & Current HIV Research & 21 & 2011 & 3.0 \\
\hline 28 & $\begin{array}{l}\text { Experiences in conducting multiple community-based HIV } \\
\text { prevention trials among women in KwaZulu-Natal, South Africa }\end{array}$ & Aids Research And Therapy & 21 & 2010 & 2.6 \\
\hline 29 & $\begin{array}{l}\text { Willingness to Participate in HIV Vaccine Trials among Men Who } \\
\text { Have Sex with Men in Chennai and Mumbai, India: A Social } \\
\text { Ecological Approach }\end{array}$ & Plos One & 20 & 2012 & 3.3 \\
\hline 30 & $\begin{array}{l}\text { Community empowerment and involvement of female sex workers } \\
\text { in targeted sexual and reproductive health interventions in Africa: } \\
\text { a systematic review }\end{array}$ & Globalization And Health & 19 & 2014 & 4.8 \\
\hline 31 & $\begin{array}{l}\text { Why Culture Matters in Health Interventions: Lessons From } \\
\text { HIV/AIDS Stigma and NCDs }\end{array}$ & Health Education \& Behavior & 18 & 2014 & 4.5 \\
\hline 32 & $\begin{array}{l}\text { Willingness of Chinese injection drug users to participate in HIV } \\
\text { vaccine trials }\end{array}$ & Vaccine & 18 & 2008 & 1.8 \\
\hline 33 & $\begin{array}{c}\text { What HIV-Positive MSM Want from Sexual Risk Reduction } \\
\text { Interventions: Findings from a Qualitative Study }\end{array}$ & Aids And Behavior & 18 & 2012 & 3.0 \\
\hline 34 & $\begin{array}{l}\text { Perceptions of barriers and facilitators to participation in clinical } \\
\text { trials in HIV-Positive latinas: A pilot study }\end{array}$ & Journal Of Womens Health & 16 & 2007 & 1.5 \\
\hline 35 & $\begin{array}{l}\text { Community-based HIV/AIDS interventions to promote } \\
\text { psychosocial well-being among people living with HIV/AIDS: a } \\
\text { literature review }\end{array}$ & $\begin{array}{l}\text { Health Psychology And } \\
\text { Behavioral Medicine }\end{array}$ & 15 & 2013 & 3.0 \\
\hline
\end{tabular}


Table 5. Cont

\begin{tabular}{|c|c|c|c|c|c|}
\hline \# & Title & Journal & Citations & Years & Cite Rate \\
\hline 36 & $\begin{array}{l}\text { Limited role of culture conversion for decision-making in } \\
\text { individual patient care and for advancing novel regimens to } \\
\text { confirmatory clinical trials }\end{array}$ & BMC Medicine & 15 & 2016 & 7.5 \\
\hline 37 & Preparedness for AIDS vaccine trials in India & $\begin{array}{l}\text { Indian Journal Of Medical } \\
\text { Research }\end{array}$ & 15 & 2008 & 1.5 \\
\hline 38 & $\begin{array}{l}\text { Community preparedness for HIV vaccine trials in the Democratic } \\
\text { Republic of Congo }\end{array}$ & Culture Health \& Sexuality & 14 & 2006 & 1.2 \\
\hline 39 & $\begin{array}{l}\text { Community-based HIV prevention interventions that combat } \\
\text { anti-gay stigma for men who have sex with men and for } \\
\text { transgender women }\end{array}$ & Journal Of Public Health Policy & 14 & 2013 & 2.8 \\
\hline 40 & $\begin{array}{l}\text { Perceptions of a community sample about participation in future } \\
\text { HIV vaccine trials in South India }\end{array}$ & Aids And Behavior & 14 & 2007 & 1.3 \\
\hline 41 & $\begin{array}{c}\text { Systematic review of stigma reducing interventions for } \\
\text { African/Black diasporic women }\end{array}$ & $\begin{array}{l}\text { Journal Of The International Aids } \\
\text { Society }\end{array}$ & 14 & 2015 & 4.7 \\
\hline 42 & $\begin{array}{l}\text { 'Rumours' and clinical trials: a retrospective examination of a } \\
\text { pediatric malnutrition study in Zambia, southern Africa }\end{array}$ & Bmc Public Health & 14 & 2010 & 1.8 \\
\hline 43 & $\begin{array}{l}\text { Gender-Specific HIV Prevention Interventions for Women Who } \\
\text { Use Alcohol and Other Drugs: The Evolution of the Science and } \\
\text { Future Directions }\end{array}$ & $\begin{array}{l}\text { Jaids-Journal Of Acquired } \\
\text { Immune Deficiency Syndromes }\end{array}$ & 12 & 2015 & 4.0 \\
\hline 44 & $\begin{array}{l}\text { The influence of social determinants on evidence-based behavioral } \\
\text { interventions-considerations for implementation in community } \\
\text { settings }\end{array}$ & $\begin{array}{l}\text { Translational Behavioral } \\
\text { Medicine }\end{array}$ & 11 & 2012 & 1.8 \\
\hline 45 & $\begin{array}{l}\text { Women, reproductive rights, and HIV/AIDS: Issues on which } \\
\text { research and interventions are still needed }\end{array}$ & $\begin{array}{l}\text { Journal Of Health Population } \\
\text { And Nutrition }\end{array}$ & 11 & 2006 & 0.9 \\
\hline 46 & $\begin{array}{c}\text { What Interventions Are Needed for Women and Girls Who Use } \\
\text { Drugs? A Global Perspective }\end{array}$ & $\begin{array}{l}\text { Journal Of Acquired Immune } \\
\text { Deficiency Syndromes }\end{array}$ & 10 & 2015 & 3.3 \\
\hline
\end{tabular}


Table 5. Cont

\begin{tabular}{|c|c|c|c|c|c|}
\hline$\#$ & Title & Journal & Citations & Years & Cite Rate \\
\hline 47 & $\begin{array}{l}\text { The preexposure prophylaxis revolution; from clinical trials to } \\
\text { programmatic implementation }\end{array}$ & $\begin{array}{l}\text { Current Opinion In HIV And } \\
\text { Aids }\end{array}$ & 10 & 2016 & 5.0 \\
\hline 48 & $\begin{array}{l}\text { Antiretroviral interventions to reduce mother-to-child transmission } \\
\text { of human immunodeficiency virus: challenges for health systems, } \\
\text { communities and society }\end{array}$ & $\begin{array}{c}\text { Bulletin Of The World Health } \\
\text { Organization }\end{array}$ & 10 & 2000 & 0.6 \\
\hline 49 & $\begin{array}{l}\text { If It's Not Working, Why Would They Be Testing It?": mental } \\
\text { models of HIV vaccine trials and preventive misconception among } \\
\text { men who have sex with men in India }\end{array}$ & BMC Public Health & 9 & 2013 & 1.8 \\
\hline 50 & $\begin{array}{l}\text { Effectiveness of Sport-Based HIV Prevention Interventions: A } \\
\text { Systematic Review of the Evidence }\end{array}$ & Aids And Behavior & 9 & 2013 & 1.8 \\
\hline
\end{tabular}




\section{Discussion}

This study reveals that the quantity and impacts, which are indicated by citations and usages, of publications on HIV-related stigma and discrimination have grown considerably, especially in recent years. Countries with large HIV populations, such as the United States of America, South Africa, China, India, and Uganda, possessed the highest number of empirical studies. Research landscapes related to stigma and discrimination include clinical, physical and mental health outcomes, risk behaviors of most-at-risk populations, and HIV-related services. We found a lack of empirical studies not only on social, cultural, and economic contexts but also on the design of specific interventions for particular contextual factors.

Findings from this study were in line with previous reviews in terms of factors associated with HIV-related stigma and discrimination. Previously, Sweileh published a review of 2509 papers relating to stigma and HIV/AIDS based on data obtained from Scopus database [25]. Nevertheless, the prior review simply focused on the bibliometric analysis without intensively examining research contents and scopes of the papers involved. Although similar trends in research growth and other bibliometric features were found in this research, since we quantified the factors associated with stigma and discrimination against HIV/AIDS patients and classified these factors into differential clusters, this study has enriched the understanding of current empirical research about stigma and discrimination and may help guide future studies. Specifically, media communication should expand the reach of existing interventions against the stigma of people living with HIV/AIDS. In addition, for designing interventions to reduce stigma, important context- and culture-specific factors should be incorporated into the characterization of causes of stigma. By precisely quantifying the frequency of research growth, we have incorporated a system-thinking perspective into the insights into HIV-related stigma and discrimination and have identified gaps, especially, about contextual factors, in the literature.

This study has several implications for improving HIV prevention, care, and treatment. It highlights a strong correlation between stigma and most at-risk populations, such as drug users, men who have sex with men and sex workers. In addition, as it is critical to eradicate stigma and discrimination in order to improve the access and utilization of HIV-related services [24,26], research on HIV-related stigma should focus more on characterizing contexts of the populations of interest, along with combining different approaches and intervention packages. An intervention, for instance, may incorporate with community-based and mass media communication to elevate its value and reduce discrimination within the population, hence, improve multiple outcomes such as mental health status, substance use, social isolation, and employment. Also, stigma and anticipated discrimination may affect patients' quality of life due to a number of features, including family context, neighborhood, and occupation. Particularly, social judgment and stigma are highly expressed in many developing countries, where HIV epidemics mainly exist in groups exhibiting specific behaviors, such as injecting drugs and being sex workers [26]. Addressing HIV-related stigma, therefore, requires concrete empirical evidence in different contexts, which might characterize its associated factors and indicate potential effects of the interventions. Also emerged from these analyses was the association of health care services and stigma. In many circumstances, patients disclose to and seek help from health workers regarding their risk behaviors and health status. Thus, sustaining stigma reduction counseling and integrating psycho-behavioral interventions into services for PLWH may make a significant contribution to the increase of service uses and reduction of stigma against HIV-positive individuals.

Although we introduced a novel approach in summarizing and analyzing the literature, some limitations should be acknowledged. First, only publications in English were selected for this study. Another limitation is that the involved databases were limited only to the Web of Science. Despite the fact that Web of Science contains a large proportion of the literature of HIV/AIDS research, it is probably not fully representative of all data. Using the WoS database for this analysis was, however, limited in its capacity to construct indicators to describe research development. For example, we could only use the total number of downloads and the mean rates of downloads for assessing the usage. Besides, the content analysis solely consisted of abstracts instead of full texts; and the construction of different types 
of articles was not fully addressed in this approach of analysis. Traditionally, bibliometric analysis only focuses on number of papers and keywords instead of involving screening of abstracts because it works with a large number of papers. We enhanced the validity of such analysis by incorporating content analysis and scrutiny of abstracts in processing data. Therefore, this modified bibliometric analysis is able to put forward a comprehensive overview of research trends as well as identify gaps in the literature of the association between HIV-related stigma and contextual factors.

\section{Conclusions}

In conclusion, stigma and discrimination against patients with HIV/AIDS continues to be an urgent issue, given the epidemic's dynamic nature in the extended life-long treatment. Future research and intervention will require a more intensive understanding of the impact of context as well as addressing the psycho-behavioral and social aspects of HIV care and treatment.

Author Contributions: Conceptualization, B.X.T., H.T.P., C.A.L. and R.C.M.H.; Data curation, B.X.T., H.L.T.N., C.L.H. and C.S.H.H.; Formal analysis, B.X.T., H.T.P., C.A.L., C.L.H. and R.C.M.H.; Methodology, B.X.T., H.T.P., H.L.T.N. and C.L.H.; Project administration, B.X.T.; Software, H.L.T.N. and C.L.H.; Supervision, B.X.T., C.A.L. and C.S.H.H.; Validation, H.T.P., C.A.L. and R.C.M.H.; Writing-original draft, B.X.T. and H.T.P.; Writing一review \& editing, B.X.T., H.T.P., C.A.L., H.L.T.N. and C.S.H.H.

Funding: This research received no external funding.

Conflicts of Interest: The authors declare no conflict of interest.

\section{References}

1. WHO. HIV/AIDS. Available online: https:/www.who.int/features/qa/71/en/ (accessed on 28 May 2019).

2. World Health Organization. Data on the size of the HIV/AIDS epidemic. Available online: http://apps.who. int/gho/data/view.main.22100WHO?lang=en (accessed on 26 January 2019).

3. Collaborators, G.H. Estimates of global, regional, and national incidence, prevalence, and mortality of HIV, 1980-2015: The Global Burden of Disease Study 2015. Lancet HIV 2016, 3, e361-e387. [CrossRef]

4. Grossman, C.I.; Stangl, A.L. Editorial: Global action to reduce HIV stigma and discrimination. J. Int. AIDS Soc. 2013, 16, 18881. [CrossRef] [PubMed]

5. Nachega, J.B.; Morroni, C.; Zuniga, J.M.; Sherer, R.; Beyrer, C.; Solomon, S.; Schechter, M.; Rockstroh, J. HIV-related stigma, isolation, discrimination, and serostatus disclosure: A global survey of 2035 HIV-infected adults. J. Int. Assoc. Phys. AIDS Care 2012, 11, 172-178. [CrossRef] [PubMed]

6. Centers for Disease, C. Pneumocystis pneumonia-Los Angeles. MMWR Morb. Mortal. Wkly. Rep. 1981, 30, 250-252.

7. Centers for Disease, C. Kaposi's sarcoma and Pneumocystis pneumonia among homosexual men-New York City and California. MMWR Morb. Mortal. Wkly. Rep. 1981, 30, 305-308.

8. Global Network of People Living with HIV (GNP+). The People Living with HIV Stigma Index. Secondary The People Living with HIV Stigma Index 2015. Available online: http://www.stigmaindex.org/ (accessed on 28 April 2019).

9. Goffman, E. Stigma: Notes on the Management of Spoiled Identity; Prentice Hall: Upper Saddle River, NJ, USA, 1963.

10. Turan, J.M.; Nyblade, L. HIV-related stigma as a barrier to achievement of global PMTCT and maternal health goals: A review of the evidence. AIDS Behav. 2013, 17, 2528-2539. [CrossRef]

11. Schuster, M.A.; Collins, R.; Cunningham, W.E.; Morton, S.C.; Zierler, S.; Wong, M.; Tu, W.; Kanouse, D.E. Perceived discrimination in clinical care in a nationally representative sample of HIV-infected adults receiving health care. J. Gen. Intern. Med. 2005, 20, 807-813. [CrossRef] [PubMed]

12. Stringer, K.L.; Turan, B.; McCormick, L.; Durojaiye, M.; Nyblade, L.; Kempf, M.C.; Lichtenstein, B.; Turan, J.M. HIV-Related Stigma Among Healthcare Providers in the Deep South. AIDS Behav. 2016, 20, 115-125. [CrossRef]

13. Alexandra Marshall, S.; Brewington, K.M.; Kathryn Allison, M.; Haynes, T.F.; Zaller, N.D. Measuring HIV-related stigma among healthcare providers: A systematic review. AIDS Care 2017, 29, 1337-1345. [CrossRef] 
14. Wagner, A.C.; Girard, T.; McShane, K.E.; Margolese, S.; Hart, T.A. HIV-Related Stigma and Overlapping Stigmas Towards People Living With HIV Among Health Care Trainees in Canada. AIDS Educ. Prev. 2017, 29, 364-376. [CrossRef]

15. Blake Helms, C.; Turan, J.M.; Atkins, G.; Kempf, M.C.; Clay, O.J.; Raper, J.L.; Mugavero, M.J.; Turan, B. Interpersonal Mechanisms Contributing to the Association Between HIV-Related Internalized Stigma and Medication Adherence. AIDS Behav. 2017, 21, 238-247. [CrossRef]

16. Fekete, E.M.; Williams, S.L.; Skinta, M.D. Internalised HIV-stigma, loneliness, depressive symptoms and sleep quality in people living with HIV. Psychol. Health 2018, 33, 398-415. [CrossRef]

17. Brown, M.J.; Serovich, J.M.; Kimberly, J.A.; Hu, J. Psychological reactance and HIV-related stigma among women living with HIV. AIDS Care 2016, 28, 745-749. [CrossRef]

18. Kamen, C.; Arganbright, J.; Kienitz, E.; Weller, M.; Khaylis, A.; Shenkman, T.; Smith, S.; Koopman, C.; Gore-Felton, C. HIV-related stigma: Implications for symptoms of anxiety and depression among Malawian women. Afr. J. AIDS Res. 2015, 14, 67-73. [CrossRef]

19. Ashaba, S.; Cooper-Vince, C.; Maling, S.; Rukundo, G.Z.; Akena, D.; Tsai, A.C. Internalized HIV stigma, bullying, major depressive disorder, and high-risk suicidality among HIV-positive adolescents in rural Uganda. Glob. Ment. Health 2018, 5, e22. [CrossRef]

20. Rasoolinajad, M.; Abedinia, N.; Noorbala, A.A.; Mohraz, M.; Badie, B.M.; Hamad, A.; Sahebi, L. Relationship Among HIV-Related Stigma, Mental Health and Quality of life for HIV-Positive Patients in Tehran. AIDS Behav. 2018, 22, 3773-3782. [CrossRef]

21. Rydstrom, L.L.; Wiklander, M.; Naver, L.; Ygge, B.M.; Eriksson, L.E. HIV-related stigma and health-related quality of life among children living with HIV in Sweden. AIDS Care 2016, 28, 665-671. [CrossRef]

22. Shrestha, R.; Copenhaver, M.; Bazazi, A.R.; Huedo-Medina, T.B.; Krishnan, A.; Altice, F.L. A Moderated Mediation Model of HIV-Related Stigma, Depression, and Social Support on Health-Related Quality of Life among Incarcerated Malaysian Men with HIV and Opioid Dependence. AIDS Behav. 2017, 21, 1059-1069. [CrossRef]

23. Katz, I.T.; Ryu, A.E.; Onuegbu, A.G.; Psaros, C.; Weiser, S.D.; Bangsberg, D.R.; Tsai, A.C. Impact of HIV-related stigma on treatment adherence: Systematic review and meta-synthesis. J. Int. AIDS Soc. 2013, 16, 18640. [CrossRef] [PubMed]

24. Rueda, S.; Mitra, S.; Chen, S.; Gogolishvili, D.; Globerman, J.; Chambers, L.; Wilson, M.; Logie, C.H.; Shi, Q.; Morassaei, S.; et al. Examining the associations between HIV-related stigma and health outcomes in people living with HIV/AIDS: A series of meta-analyses. BMJ Open 2016, 6, e011453. [CrossRef]

25. Sweileh, W.M. Bibliometric analysis of literature in AIDS-related stigma and discrimination. Transl. Behav. Med. 2018, 10, 10. [CrossRef]

26. Thapa, S.; Hannes, K.; Cargo, M.; Buve, A.; Peters, S.; Dauphin, S.; Mathei, C. Stigma reduction in relation to HIV test uptake in low- and middle-income countries: A realist review. BMC Public Health 2018, 18, 1277. [CrossRef] [PubMed]

(C) 2019 by the authors. Licensee MDPI, Basel, Switzerland. This article is an open access article distributed under the terms and conditions of the Creative Commons Attribution (CC BY) license (http://creativecommons.org/licenses/by/4.0/). 